\title{
Interannual variability in nitrate supply to surface waters of the Northeast Pacific Ocean
}

\author{
F. A. Whitney ${ }^{1, *}$, C. S. Wong ${ }^{1}$, P. W. Boyd ${ }^{2}$ \\ 'Institute of Ocean Sciences, PO Box 6000, Sidney, Brítish Columbia V8L 4B2, Canada \\ ${ }^{2}$ University of Otago, Dunedin, New Zealand
}

\begin{abstract}
In the past decade, the upper ocean in the NE Pacific has undergone changes in physical and chemical properties which are similar to the recent El Niño/La Niña cycle. During the 1989 La Niña, winter waters at Ocean Station Papa (OSP) were relatively cool, saline and nitrate rich. With the onset of the $1991 \mathrm{El} \mathrm{Niño} \mathrm{period,} \mathrm{however,} \mathrm{winter} \mathrm{waters} \mathrm{at} \mathrm{OSP} \mathrm{were} \mathrm{more} \mathrm{saline} \mathrm{by} 0.3$ psu, warmer by over $2^{\circ} \mathrm{C}$ and nitrate depleted by $30 \%$. In 1994, oceanic winter temperatures were the warmest ever observed in over $40 \mathrm{yr}$ of sampling. The decrease in winter nutrient supply persisted eastward from OSP to the coast of Vancouver Island, and resulted in an expanded area of nitrate depletion in summer. Lower winter nitrate supply is estimated to have reduced new production through spring and summer by $40 \%$ ( 2 million tonnes C) in a $290000 \mathrm{~km}^{2}$ patch of ocean west of Vancouver Island. We suggest that declines in phytoplankton production of this magnitude affect both the productivity and composition of higher trophic levels.
\end{abstract}

KEY WORDS: Northeast Pacific · Alaskan Gyre - Mixed layer - Nitrate $\cdot$ Temperature - Salinity El Nino New production - Interannual variability

\section{INTRODUCTION}

Nutrient supply and sunlight are primary controls of phytoplankton growth in the ocean. In northern subarctic regions, winter growth is limited by the supply of solar energy to a relatively deep mixed layer, whereas spring and summer controls are thought to be a combination of nutrient limitations and grazing pressure (Parsons \& Lalli 1988).

Although the annual cycle of macronutrient (nitrate, phosphate and silicate) uptake and resupply is well documented in the open NE Pacific (Anderson et al. 1969, Archer et al. 1993, Wheeler 1993), processes that regulate the supply are not well understood. Archer et al. (1993) attempted to model the annual cycle of nitrate in the mixed layer at OSP (Ocean Station Papa), and concluded that a 1-dimensional model was not adequate to reproduce observed trends. Their analysis suggested that winter mixing alone is not adequate to resupply the upper ocean with nitrate, but that there

•E-mail: whitneyf@dfo-mpo.gc.ca must be transport along isopycnals. Wheeler (1993) estimated the horizontal and vertical inputs of nitrate in spring as being a substantial portion of the observed daily uptake by phytoplankton, and found that these sources became a more important component of the nitrogen budget towards late summer.

Warm periods in the NE Pacific Ocean are related to El Niño events which, when initiated, persist for several years (Wooster \& Hollowed 1995). Simpson (1992) remarked on the increased northern flow of water along the California coast during the $1982 \mathrm{El}$ Niño; this warm water mass was clearly observed in waters off the coast of Vancouver Island, British Columbia (Tabata 1985). Variability in northern flow apparently results from a strengthening of the Aleutian low which creates stronger winds from the south and intensifies circulation around the Alaska Gyre (Mysak 1986, Wooster \& Hollowed 1995). The recent warming of the Gulf of Alaska, which appears to be a response to the prolonged El Niño period of the early 1990s, is part of a longer trend which has been observed since the 1970 s (Kleeman et al. 1996). Freeland 


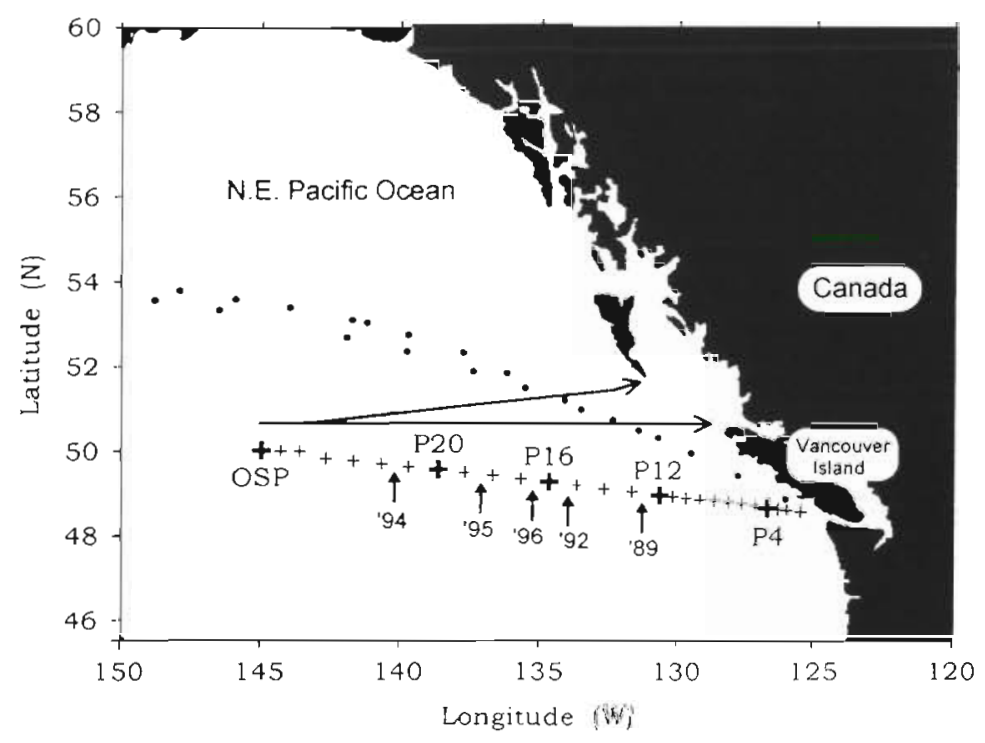

Fig. 1. The Northeast Pacific Ocean showing station locations along Line $P(+)$, sample locations on typical Skaugran voyages $(\bullet)$ and paths of 2 return sections that have been occasionally sampled (lines with arrows). Shown also are the western limits of nitrate depletion in late summer for various years $(\uparrow)$

et al. (1997) have described a long term warming freshening and shoaling of the mixed layer at OSP, which they argue is cause for concern over the future nutrient supply to this region. Indeed, Gargett (1997) suggests that enhancement of water column stability associated with warming could increase production in northern Gulf of Alaska fish stocks by increasing light levels for phytoplankton. in nutrient rich waters, while southern stocks would weaken as nutrient supply dwindled.

Waters off the west coast of Canada can be divided into 3 regions based on macronutrient supply and utilization. In 'coastal' waters which extend about $75 \mathrm{~km}$ across the continental shelf, productivity is stimulated during summer by periods of upwelling (Freeland \& Denman 1982). Oxygen poor, nutrient rich California Undercurrent waters are a major component of this water mass (Mackas et al. 1987) which supports a productive fishery (Ware \& McFarlane 1995). Oceanic waters are characterized by high macronutrients and low chlorophyll (HNLC). In the vicinity of OSP, nitrate fluctuates by about $7 \mu \mathrm{M}$ each year through the cycle of summer uptake and winter replenishment (Anderson et al. 1969. Archer et al, 1993), leaving at least $5 \mu \mathrm{M} \mathrm{NO}_{3}$ unused in late summer. Yet throughout the year, chlorophyll concentrations remain low (Boyd et al. 1995, Wong et al. 1995). Between coastal and oceanic waters lies a 'transition' area that is unaffected by coastal upwelling and experiences nitrate depletion in summer. This area has not been well described in properties such as nutrients or biological productivity, although it appears associated with a seasonal spread of fresh water westward from the continent, as defined in the 1950 s and 1960 s by Dodimead et al. (1963) and Favorite et al. (1976).

Although nitrate commonly limits phytoplankton growth in the coastal and open ocean, the micronutrient iron is currently believed to be in critically short supply in 3 ocean regions including the subarctic Pacific (Martin et al. 1991). Iron is apparently insufficient to permit phytoplankton to utilize all available nitrate in these areas. A recent Gulf of Alaska survey, which used the biochemical marker flavodoxin to assess iron stress (La Roche et al. 1996), indicated that the phytoplankton resident in transition and coastal waters are not iron stressed, therefore nitrate supply likely controls production. But in the oceanic realm, the presence of flavodoxin and diatom response to iron enrichment in in vitro experiments (Boyd et al. 1995) demonstrated iron limitation. Thus, iron depletion becomes a further characteristic of the oceanic waters.

In this paper, physical, chemical and biological data from the past decade are presented from the Line $P$ transect that extends from the coast of Vancouver Island to OSP, from additional sections completed on Line P cruises, and from commercial ships of opportunity traversing the Subarctic Pacific Ocean. These data provide a record of the interannual variability in nitrate supply and utilization that has occurred in coastal, transition and oceanic regions over the past decade.

\section{MATERIALS AND METHODS}

The Line P program, which has been operating since 1959 , routinely surveys water properties from the coast of Vancouver Island to the HNLC waters of the NE Pacific (Fig. 1)

The $1500 \mathrm{~km}$ section is sampled several times most years, and in the past decade, nutrients have been analyzed from all cruises. Sampling typically occurs in late winter (February or March) when waters are coldest and the mixed layer deepest, spring (April to June) when plankton activity increases, and late summer (August to October) when waters are warmest and the mixed layer thinnest. The participation of CJGOFS (Canadian Joint Global Ocean Flux Study) and WOCE (World Ocean Circulation. Experiment) programs on Line P cruises in the past several years has resulted in more detailed sampling of water properties and plankton 
Samples were taken from the Canadian RVs 'CSS Parizeau', 'CNAV Endeavour' and 'CSS John P. Tully' over the past $10 \mathrm{yr}$ Since 1988, surface samples for salinity and macronutrients have been collected at each station from a clean sea water line that pumps water from a nominal depth of $5 \mathrm{~m}$ to a shipboard laboratory. Weather allowing, CTD profiles were collected at every station using high precision Guildline and Sea-bird CTDs, whereas chemical and biological properties were profiled at no more than 5 stations $(\mathrm{P} 4$, $12,16,20$ and OSP)

Additional salinity and macronutrient samples were collected by officers and scientists on commercial ships of opportunity running between Canada and Japan between 1987 and 1990 (MV 'Canadian Ace') and 1994 and 1997 (MV 'Skaugran'). Nutrients were frozen and stored for up to 6 mo before being analyzed.

Complete seasonal and spatial coverage of the study area was not always possible. In 1994, due to persistent high winds, the winter survey was halted between P23 and P24, $190 \mathrm{~km}$ from OSP. Gradients observed along Line $\mathrm{P}$ on other winter surveys $\left(0.25^{\circ} \mathrm{C}\right.$ per $100 \mathrm{~km}$, $0.02 \mathrm{psu}$ per $100 \mathrm{~km}, 0.6 \mu \mathrm{M} \mathrm{NO} 3$ per $100 \mathrm{~km}$ ) have been used to estimate conditions at OSP in February 1994. When winter CTD profiles were not available to estimate water temperatures at OSP, early spring data were used, and seasonal warming was removed by reducing temperatures in the upper mixed layer to that at $75 \mathrm{~m}$ (May 1988 and May 1990). The $75 \mathrm{~m}$ temperatures appeared uncontaminated by spring warming, and were still within the layer that was mixed during winter storms.

Sea-Tech transmissometers with a $25 \mathrm{~cm}$ path length were used in recent cruises to measure the distribution of particles in the upper $200 \mathrm{~m}$ of the ocean. Salinities were collected with all nutrient samples and analyzed using a Guildline Autosal or Portasal salinometer standardized with IAPSO standard seawater.

Nitrate plus nitrite was analyzed on a Technicon AutoAnalyzer following modified Technicon procedures that are detailed in Barwell-Clarke \& Whitney (1996). On several cruises, nitrite was independently analyzed and was not found to exceed $0.3 \mu \mathrm{M}$. Most of the $T, S$, light transmission and nutrient data used in this study have been submitted to WOCE Hydrographic Program Office as part of the Line PR6 repeat hydrography program, and/or to Marine Environmental Data Service (MEDS) in Ottawa, Canada, as a contribution to the CJGOFS Program.

Primary production rates were measured by enriching seawater with $\mathrm{NaH}^{14} \mathrm{CO}_{3}$ and incubating samples at light levels similar to those from which they were taken, in a deck incubator that is temperature regulated to within $2^{\circ} \mathrm{C}$ of ambient seawater. Care was taken throughout sampling (with Go-Flo samplers on kevlar line) and handling to avoid trace metal contamination (Boyd et al. 1995). Production measurements were integrated from the surface $(100 \%$ light level) to the bottom of the euphotic zone $1 \%$ light level).

Data from NOAA's web site at http://nic.fb4.noaa. gov/data/cddb/cddb/soi were used to plot the Southern Oscillation Index. The index is a measure of the anomaly in sea level pressure measured between Tahiti and Darwin, Australia.

\section{RESULTS}

\section{OSP winter trends}

The macronutrient cycle in the NE Pacific follows an annual pattern in which maximum concentrations (the winter reserve) are observed in February/March when the mixed layer is deepest and primary productivity is slowest, and minima occur in late summer following the spring/summer period of reduced winds and elevated phytoplankton activity (Anderson et al. 1969, Tabata 1976, Wong et al. 1995). By initially focussing on water property changes in late winter, interannual variability in the supply of macronutrients to the upper ocean can be observed.

In the past decade, late winter temperatures in the upper ocean have varied by over $2^{\circ} \mathrm{C}$ (Fig. 2). Between 1989 and the end of the recent warm period in 1994 , surface temperatures increased from 4.6 to an estimated $6.8^{\circ} \mathrm{C}$. The combination of these trends increased the buoyancy of surface waters (decrease of sigma $t$ by 0.4 ). With the exception of the estimated $6.8^{\circ} \mathrm{C}$ temperature in 1994 , which is the warmest February/March temperature on record, these values fall within the range of historical surface values for February at $\operatorname{OSP}\left(\mathrm{T}=4.2\right.$ to $6.7^{\circ} \mathrm{C}$ and $\mathrm{S}=32.46$ to 32.90 from 1956-81 data of Tabata \& Peart 1985, Whitney unpubl. 1982-86 data; Fig. 2). To confirm whether 1994 was the warmest winter that has been observed, comparisons were made at other oceanic stations (P18 to P24) which showed that waters were over $0.5^{\circ} \mathrm{C}$ warmer than previous winter highs (Tabata \& Peart 1985, Whitney unpubl. 1982-97 data). For example, at Stn P20 in February 1994 , an $8.0^{\circ} \mathrm{C}$ surface temperature exceeded the previous $7.2^{\circ} \mathrm{C}$ maximum recorded in February/March between 1959 and present (Tabata \& Peart 1985, Whitney unpubl. 1982-86 data; Fig. 2).

Elevated water temperatures in the early 1990 s were observed below the mixed layer (Fig. 2), to a depth of at least $300 \mathrm{~m}$. In 1994 (data scaled from Stn P23) and 1995, temperatures between 150 and $200 \mathrm{~m}$ were $2^{\circ} \mathrm{C}$ higher than those of 1989. White (1994) has observed subsurface heat transport northward along the coast of 


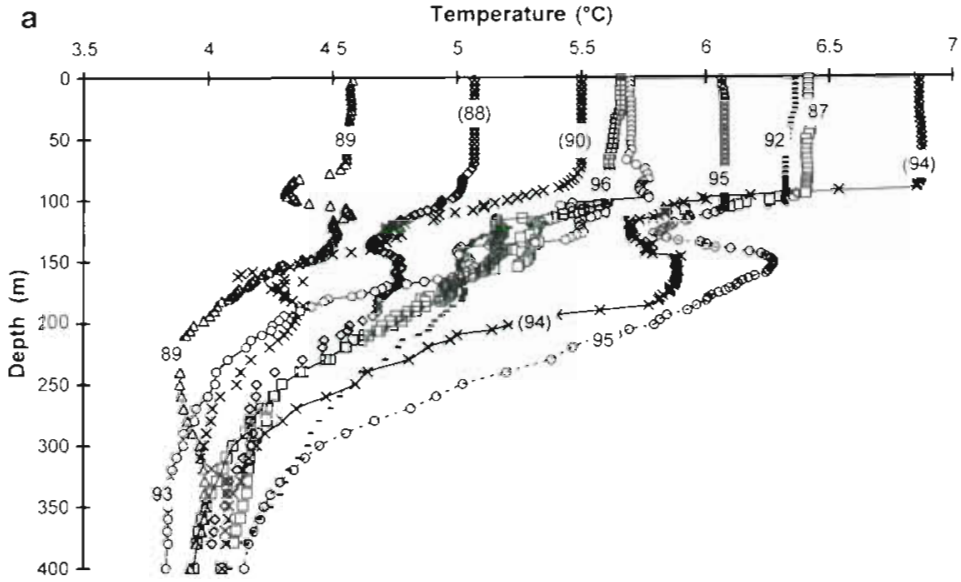

b

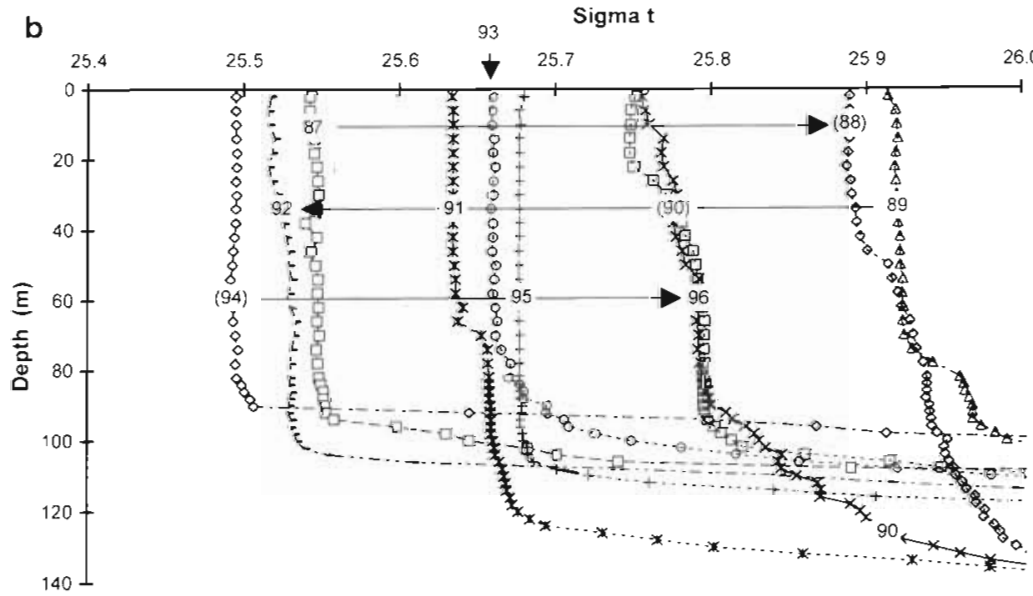

Fig. 2. (a) Winter temperature profiles at OSP from 1987 to 1996. (b) Density profiles at OSP in late winter from 1987 to 1996. Arrows show the cyclical nature of the changes that occurred in the past decade

riod (1991-94), the winter nitrate reserve decreased to $12 \mu \mathrm{M}$ and has remained relatively low over the ensuing 3 winters.

Salinity and temperature at OSP and changes in the equatorial atmosphere follow similar trends in the past decade. During the strongly positive 1989 and weakly positive 1996 Southern Oscillation Index (Fig. 3), salinity was high and surface waters were cool. As the SOI began to turn negative through 1990-91 as the El Niño period started, salinity decreased by 0.3 psu and waters warmed. Warming persisted through to 1994 , even though salinity began to increase. The lowest nitrate levels of this period coincided with the most buoyant winter surface layer (Fig. 2) and warmest waters. Since this prolonged period of negative SOI, winter nitrate concentrations at OSP have remained low (about $13 \mu \mathrm{M}$ compared with the average winter $\mathrm{NO}_{3}$ $=15.3 \pm 2.7 \mu \mathrm{M}, 1971$ to 1997 ; data from Freeland et al. 1997 and this study).

\section{Seasonal trends along Line $\mathbf{P}$}

The winter temperature and salinity trends seen at OSP are common to oceanic stations along Line P (Fig. 4). Away from the coast, waters were coldest and most saline in 1989. Again, we see that lowest salinities are observed 2 yr before the warmest temperatures. Nearer shore, waters were much fresher

North. America but the process for transporting this heat offshore, into the Alaskan Gyre, is unknown. Surface drifters have been observed to head southward from the coast of Alaska, along the western edge of the gyre (R. Thomson, Institute of Ocean Sciences, pers. comm.), so subsurface flow likely follows the same path.

Both $\mathrm{T}$ and $\mathrm{S}$ trends combine to decrease the density of waters in the mixed layer through the warm periods in 1987 and 1992-94. Densities appear to be correlated with the depth of the mixed layer in many winters (Fig. 2) so that when waters were most buoyant in 1987 and 1994, the depth of mixing had decreased to about $90 \mathrm{~m}$. When waters were denser in 1988, 1990 and 1991, the mixed layer was deeper, penetrating to $120 \mathrm{~m}$ in 1991 (Fig. 2). During the 1988-89 period in which surface waters were densest, winter nitrate levels reached the highest concentrations recorded during the past decade (Fig. 3). Through the most recent warm pe- in 1989-90 and 1996 when oceanic salinities were highest; accumulations of coastal fresh water were lower through the El Niño period.

Winter nitrate levels decreased from 1989 through 1994 in offshore waters (Fig. 5). By 1994, nitrate concentrations along Line $\mathrm{P}$ were only $60 \%$ those of 1989-90 (50\% in transitional. waters).

The effect of the decreased winter supply of macronutrients is apparent in late summer (Fig, 5). In 1989 $90, \mathrm{NO}_{3}$ depletion was observed seaward to Stn P12, offshore some $250 \mathrm{~km}$. By 1994, NO 3 depletion had spread $600 \mathrm{~km}$ offshore, to the vicinity of Stn P22. The oceanic boundary of this nutrient poor transition zone is marked by an increase in salinity of about 0.2 psu and occurs near the 32.4 isohaline. Through 1995-96, the offshore spread of the transition waters had retreated so that it extended some $400 \mathrm{~km}$ off the coast of Vancouver Island. The area of nitrate depletion in summer is forecast by the winter resupply, so that if 

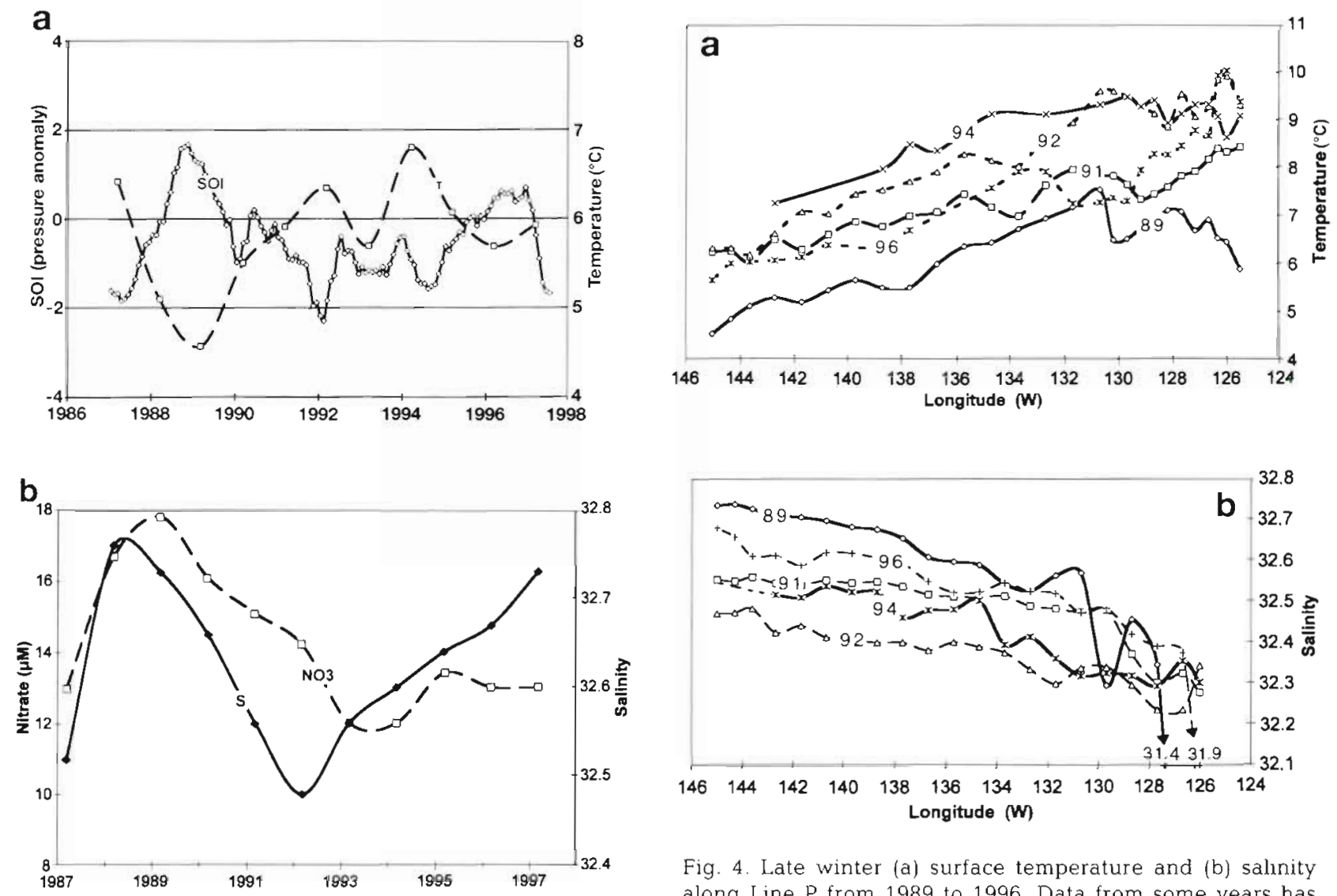

Fig. 4. Late winter (a) surface temperature and (b) salunity along Line P from 1989 to 1996 . Data from some years has been omitted to simplify the graph

Fig. 3. (a) The Southern Oscillation Index ( $0: 5$ mo averages) which depicts the anomaly of sea surface pressure across the equatorial Pacific and winter temperature (D) of surface waters at OSP. (b) Average late winter salinity $(\bullet$ ) and nitrate (ㅁ) in surface waters at OSP

winter waters do not have more than $7 \mu \mathrm{MNO}$, they become nitrate limited in summer.

\section{Impacts on primary productivity}

Using data from ships of opportunity and Line $P$ cruises, it is possible to estimate the impact on new production (nitrate based phytoplankton growth) over an area that is bounded by the continental shelf of Vancouver Island on the east, $49^{\circ} \mathrm{N}$ to the south, $51^{\circ} \mathrm{N}$ to the north and $145^{\circ} \mathrm{W}$. This area is further divided into 2 regions that approximately represent the transitional zone which experiences annual nitrate depletion (P4 to P16, $130000 \mathrm{~km}^{2}$ ), and oceanic waters which stay nitrate replete (P16 to P26, $160000 \mathrm{~km}^{2}$ ), although the boundary between these 2 areas varies interannually between P12 and P22. It is not possible to estimate changes in nutrient supply to the coastal area with a seasonal sampling program, although it is likely that

primary production also decreased in this area through 1994-95, since summer upwelling was weaker at this time than in other years (coastal upwelling index at $48^{\circ} \mathrm{N}, 125^{\circ} \mathrm{W}$, data from Pacific Fisheries Environmental Laboratory, NOAA, Pacific Grove, California). New production (NP) in Table 1 is calculated using the observed $\mathrm{NO}_{3}$ uptake between winter and late summer, a C:N ratio of 6.6 , and an estimate that nitrate uptake occurred in the upper $40 \mathrm{~m}$ of the water column (scaling $\mathrm{NO}_{3}$ uptake by a factor of 40 was estimated by measuring seasonal $\mathrm{NO}_{3}$ removal in the upper $150 \mathrm{~m}$ on several occasions at Stns P20 and P26 and dividing this integrated value by the surface uptake). A decrease in NP of about 2 million tonnes $\mathrm{C}$ in the spring-summer growing period between 1992 and 1994 mainly occurs in transition waters where nitrate is exhausted by September. In the transition area, NP decreased by almost $50 \%$ over these 3 yr.

In 4 years during the past decade, surface waters were sampled over a broad enough area to permit estimates of the area of nitrate depletion between 49 and $51^{\circ} \mathrm{N}$ (Table 2). Early in this period, nitrate was typically depleted out to Stn P12 along Line P, and was not depleted off the northern end of Vancouver Island. By 

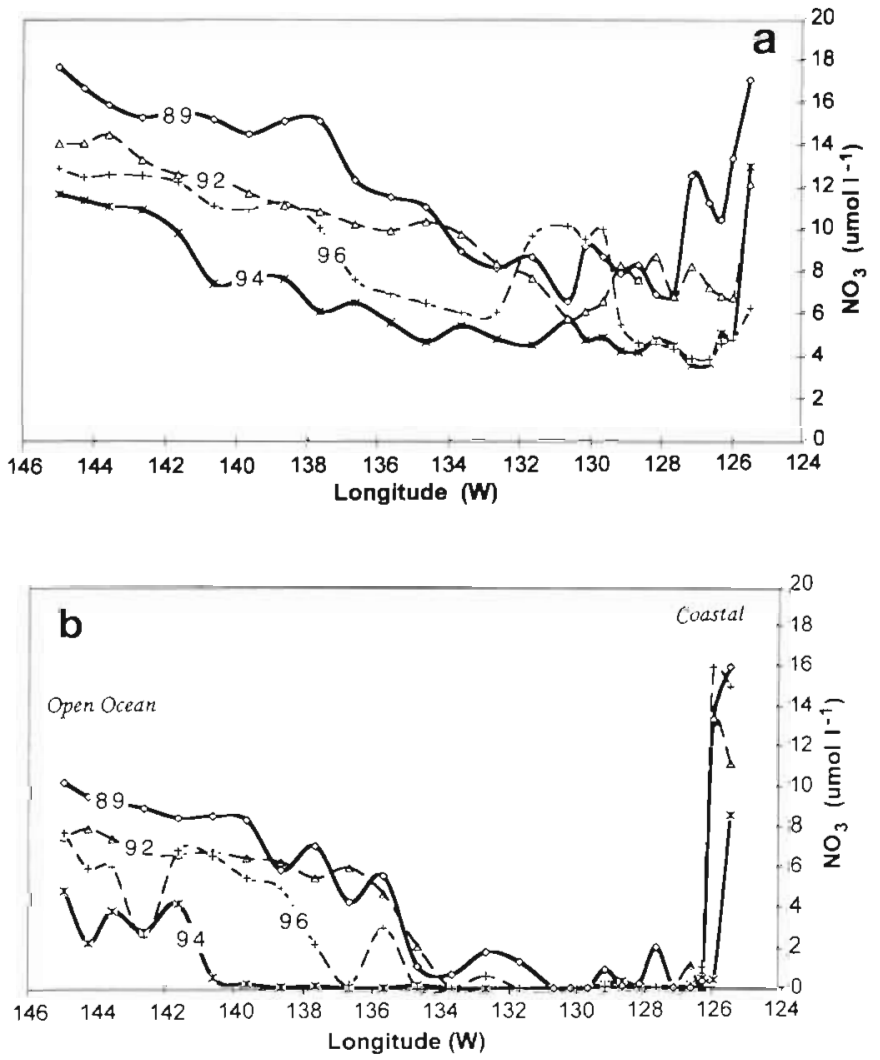

Fig. 5. (a) Late winter and (b) late summer nitrate from surface waters along Line $\mathrm{P}$

Table 1. Estimates of average nitrate uptake and the new production (NP) in 2 regions between February/March and August/September. Between $49^{\circ}$ and $51^{\circ} \mathrm{N}$, transition waters (P4-P16) cover a $130000 \mathrm{~km}^{2}$ area and offshore waters (P16-P26) cover $160000 \mathrm{~km}^{2}$

\begin{tabular}{|ccccc|} 
Year & $\begin{array}{c}\mathrm{NO}_{3} \text { uptake } \\
\mathrm{P} 4-\mathrm{P} 16 \\
\left(\mu \mathrm{mol} \mathrm{I}^{-1}\right)\end{array}$ & $\begin{array}{c}\text { Total NP } \\
\mathrm{P} 4-\mathrm{P} 16 \\
\left(\times 10^{6} \mathrm{t}\right)\end{array}$ & $\begin{array}{c}\mathrm{NO}_{3} \text { uptake } \\
\mathrm{P} 16-\mathrm{P} 26 \\
\left(\mu \mathrm{mol} \mathrm{I}^{-1}\right)\end{array}$ & $\begin{array}{c}\text { Total NP } \\
\left(\times 10^{5} \mathrm{t} \text { C }\right)\end{array}$ \\
\hline 1989 & 8.0 & 3.2 & 7.5 & 3.7 \\
1991 & 9.0 & 3.6 & 7.5 & 3.7 \\
1992 & 7.5 & 3.0 & 6.0 & 3.0 \\
1994 & 4.6 & 1.9 & 6.8 & 3.4 \\
1995 & 6.1 & 2.4 & 7.2 & 3.6 \\
1996 & 6.8 & 2.7 & 6.4 & 3.2 \\
\hline
\end{tabular}

Table 2. Estimates of nitrate depletion areas off the west coast of Vancouver Island, between $49^{\circ}$ and $51^{\circ} \mathrm{N}$, in selected years

\begin{tabular}{|cc|}
\hline Year & Area $\left(\mathrm{km}^{2}\right)$ \\
\hline 1989 & $40-70000$ \\
1994 & 176000 \\
1995 & 148000 \\
1996 & 126000 \\
\hline
\end{tabular}

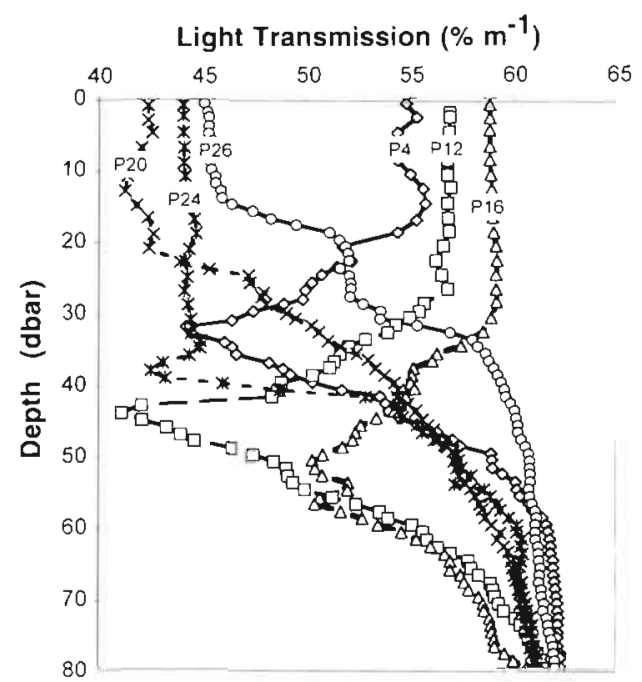

Fig. 6. Light transmission protiles at stations along Line $\mathrm{P}$ in August 1995

1994, depletion covered about 3 times the area, and was evident well offshore along $51^{\circ} \mathrm{N}$.

A result of nitrate depletion in transition zone waters is that phytoplankton concentrate subsurface, at the top of the nutricline, and are sparser near the surface. In August, 1995, transmissometer traces show a subsurface particle stratum at stations where nitrate is depleted (Fig. 6). The depth of the light transmission minimum increases with distance from the coast and with clarity of surface waters. Seaward of this region in oceanic waters, particles are evenly distributed in the surface mixed layer and are more abundant within the euphotic zone. Chlorophyll a data (Whitney unpubl.) confirm that the transmissometer provides a good estimate of phytoplankton distribution.

From the 3 years in which primary production measurements were made in late summer along Line $P$, areas of low and high production can be identified. Phytoplankton production (Table 3 ) is $580 \pm 180 \mathrm{mg} \mathrm{C}$ $\mathrm{m}^{-2} \mathrm{~d}^{-1}$ in nitrate depleted transition waters of late summer, compared with rates of $920 \pm 160 \mathrm{mg} \mathrm{C} \mathrm{m}{ }^{-2}$ $\mathrm{d}^{-1}$ in nitrate replete oceanic waters. Rates are higher both in coastal waters (P4 in 1992 and 1996) which are

Table 3. Primary productivity $\left(\mathrm{mg} \mathrm{C} \mathrm{m}^{-2} \mathrm{~d}^{-1}\right.$ ) in late summer for waters that are nitrate depleted (-), nitrate replete $(+)$ or lie in a frontal region (f) between these areas

\begin{tabular}{|lccc|}
\hline Stn & Sep 1992 & Aug/Sep 1995 & Aug 1996 \\
\hline P4 & $2000+$ & $480-$ & $2400+$ \\
P12 & $760-$ & $390-$ & $850-$ \\
P16 & $1600 \mathrm{f}$ & $510-$ & $490-$ \\
P20 & $1100+$ & $1300 \mathrm{f}$ & $1030+$ \\
OSP & $920+$ & $710+$ & $830+$ \\
\hline
\end{tabular}


enriched in summer with upwelled nutrients, and in a frontal zone between transition and oceanic waters (P16 in 1992 and near P20 in 1995).

\section{DISCUSSION}

It is the aim of this paper to demonstrate that there are interannual changes in seawater properties in the NE Pacific Ocean which affect nutrient supply, primary production, and by inference, higher trophic level productivity. Atmospheric, oceanic and biological processes work in concert to produce the cyclical changes seen in temperature, salinity and nitrate over the past decade in the portion of the Gulf of Alaska that our sampling has allowed us to observe.

The link made between El Niño events and mixed layer water properties along Line $P$ suggests that the variability we are observing in the NE Pacific is not regional, but results from changes in atmosphere forcing that likely affect the entire North Pacific. Such a connection has not been convincing in past Gulf of Alaska studies. For example, Royer (1989) observed that the 1958 El Niño took 3 yr to move through the NE Pacific, whereas the 1983 event appeared in surface seawater temperature simultaneously throughout the region. Understanding poleward heat flux from El Niños improved with White's (1994) analysis which showed that this transport can be continuously tracked when observations are made to a depth of $400 \mathrm{~m}$, rather than just at the surface where the signal may be lost. The transit time for such a heat pulse to reach the Gulf of Alaska from the equator varied from 9 to $18 \mathrm{mo}$ in his analysis. Variability in both the Aleutian low pressure system and in sea level pressure across the equatorial Pacific have been shown to correlate with warm events in the California Current (Norton \& McLain 1994). These authors find that $E l$ Niño signals are best observed in subsurface waters to $300 \mathrm{~m}$ depth, whereas influences of the Aleutian low are only seen in the surface layer. At OSP, we have observed considerable warming to $300 \mathrm{~m}$, in an area that is $900 \mathrm{~km}$ from land.

There is evidence that warming in the North Pacific is not only cyclical. Warming trends of $0.8^{\circ} \mathrm{C}$ in a $42 \mathrm{yr}$ time series (Roemmich 1992) along the California coast and of about $1^{\circ} \mathrm{C}$ per century from a 60 yr record along the British Columbia coast (Freeland et al. 1997) suggest we may be seeing an effect of increasing global temperatures. Kleeman et al. (1996) suggest this oceanic warming trend started in the early 1970 s and results from a change in changes in atmospheric circulation; data presented by Freeland et al. (1997) support this contention by showing a mid 1970s step in the trend of decreasing surface seawater density in the Gulf of Alaska.
Regardless of the physical forcing that causes warm periods in the NE Pacific, it is evident that macronutrient supply to the mixed layer was modulated over the past decade in a pattern very similar to that of the Southern Oscillation Index. In concert, winter water density, mixed layer depth and the nitrate supply changed. As a consequence of these changes, there was only $50 \%$ as much $\mathrm{NO}_{3}$ available to phytoplankton in transition waters in the spring of 1994, compared with 1991. Because these waters become nitrate depleted in summer, this reduced nutrient supply results in a substantial decline in new production.

Of the major nitrogen sources that support phytoplankton growth, only nitrate is resupplied to surface waters annually in amounts great enough to support biomass production. Limitation of its supply will impact zooplankton and fish production. Iverson's food web model (1990) shows that a $50 \%$ reduction in nitrate utilization would cause an equal reduction in carnivorous fish growth. Seaward of the continental shelf off Vancouver Island, any fish stocks that depend on this habitat for growth and survival would have experienced lean times in mid-1990s. Recent decreases in some southern British Columbia salmon stocks (Mantua et al. 1997, Welch et al. 1997, D. Welch, Pacific Biological Station, Nanaimo, British Columbia, pers. comm.) may have arisen from these reductions in macronutrient supply off the Vancouver Island coast.

A rather uniform increase in nitrate is observed westward along Line P. Thus as winter supply dwindles, late summer depletion is seen to spread seaward from the coast, encompassing a substantially larger area in 1994 than in 1989. Since this nutrient poor transition area is a relatively fresh water pool that is bounded to the west by the surface 32.4 isohaline, this may also define an area that is enriched with iron from continental runoff. La Roche et al. (1996) have observed iron limitation along Line $P$ only within the oceanic water mass.

Nitrate depletion changes the habitat in which phytoplankton grow, from one in which cells are evenly distributed through the mixed layer, to one of a subsurface chlorophyll maximum. Along Line $P$, summer primary productivity is about half as much when nitrate is depleted. This dual impact of reduced growth and redistribution of cells creates an altered habitat for grazers. Fulton \& LeBrasseur (1985) observed a shift from large to small copepods in this area during the $1958 \mathrm{El} \mathrm{Niño,} \mathrm{which} \mathrm{suggests} \mathrm{a} \mathrm{change}$ also in either the abundance or size distribution of phytoplankton. Simpson (1992) described similar conditions in the California Current system during the 1982 El Niño. He found that phytoplankton maxima occurred much deeper and zooplankton populations reached record lows. A striking effect of warming and 
reduced macronutrient supply in the surface waters of California coastal waters over the last 40 yr has been an $80 \%$ reduction in zooplankton biomass (Roemmich \& McGowan 1995), which has also affected sea bird populations (Veit et al. 1996). Off the northern end of Vancouver Island, roosting sea bird colonies have recently been suffering depressed breeding success, apparently due to food shortages (D. Bertram, Simon Fraser University, Vancouver, British Columbia, pers. comm.)

Whether variations in mixed layer density that have been observed along Line $\mathrm{P}$ in the past decade are part of the ocean's response to greenhouse warming or are part of multi-decadal cycles in ocean and atmosphere interactions is not clear. However, the effects they have on macronutrient supply and plankton production are dramatic. As management of fish stocks becomes more contentious, gaining a better understanding of the role that oceanic change plays in the success or failure of stocks will become crucial. The fear that increases in greenhouse gases are causing these observed changes (Woods \& Barkmann 1993) leads to the hypothesis that the productivity of the Gulf of Alaska may substantially decrease as the surface ocean becomes more buoyant through warming

\section{LITERATURE CITED}

Anderson GC, Parsons TR, Stephens K (1969) Nitrate distribution in the subarctic Northeast Pacific Ocean. Deep-Sea Res 16:329-334

Archer D, Emerson S, Powell T, Wong CS (1993) Numerical hindcasting of sea surface $\mathrm{pCO}_{2}$ at Weathership OSPapa. Prog Oceanogr 32:319-351

Barwell-Clarke J, Whitney F (1996) Institute of Ocean Sciences nutrient methods and analysis. Can Tech Rep Hydrogr Ocean Sci 182: vi $+43 p$

Boyd PW, Whitney FA, Harnson PJ, Wong CS (1995) The NE subarctic Pacific in winter. II. Biological rate processes. Mar Ecol Prog Ser 128:25-34

Dodimead AJ, Favorite F, Hirano T (1963) Review of oceanography of the Subarctic Pacific region. Int North Pac Fish Comm Bull 13

Favorite F, Dodirnead AJ, Nasu K (1976) Oceanography of the subarctic Pacific region, 1960-71. Int North Pac Fish Comm Bull 33

Freeland HJ, Denman KL (1982) A topographically controlled upwelling center of southern Vancouver Island. J Mar Res 40:1069-1093

Freeland HJ, Denman K, Wong CS, Whitney F, Jacques R (1997) Evidence of change in the winter mixed layer in the Northeast Pacific Ocean. Deep-Sea Res 44:2117-2129

Fulton JD, LeBrasseur RJ (1985) Interannual shifting of the Subarctic boundary and some of the biotic effects on juvenile salmonids. In: Wooster WS, Flaherty DL (eds) El Niño North; Nino effects in the eastern subarctic Pacific Ocean. Washington Sea Grant Program, Seattle, p 237-247

Gargett AE (1997) The optimal stability 'window': a mechanism underlying decadal fluctuations in North Pacific salmon stocks? Fish Oceanogr 6:109-117
Iverson RL (1990) Control of marine fish production. Limnol Oceanogr 35:1593-1604

Kleeman R, Colman RA, Smith NR, Power SC (1996) A recent change in the mean state of the Pacific basin climate: observational evidence and atmospheric responses. J Geophys Res 101:20483-20499

La Roche J, Boyd PW, McKay RML, Geider RJ (1996) Flavodoxin as an in situ marker for iron stress in phytoplankton. Nature 382:802-805

Mackas DL, Denman KL, Bettett AF (1987) Least squares multiple tracer analysis of water mass composition. J Geophys Res 92:2907-2918

Mantua NJ, Hare SR, Zhang Y, Wallace JM, Francis RC (1997) A Pacific interdecadal climate oscillation with impacts on salmon production. Bull Am Meteorol Soc 78:1069-1079

Martin JH, Gordon M, Fitzwater SE (1991) The case for iron Limnol Oceanogr 36:1793-1802

Mysak LA (1986) El Niño, interannual variability and fisheries in the Northeast Pacific Ocean. Can J Fish Aquat Sci 43 . 464-497

Norton JG, McLain DR (1994) Diagnostic patterns of seasonal and interannual temperature variation off the west coast of the United States: local and remote large-scale atmospheric forcing. J Geophys Res 99:16019-16030

Parsons TR, Lalli CM (1988) Comparative oceanic ecology of the plankton communities of the subarctic Atlantic and Pacific Oceans. Oceanogr Mar Biol Annu Rev 26:317-359

Roemmich D (1992) Ocean warming and sea level rise along the Southwest US coast. Science 257:373-375

Roemmich D, McGowan J (1995) Climatic warming and the decline of zooplankton in the California Current. Science 267:1324-1326

Royer TC (1989) Upper ocean temperature variability in the Northeast Pacific Ocean: is it an indication of global warming? J Geophys Res 94:18175-18183

Simpson JJ (1992) Response of the Southern California current system to the mid-latitude North Pacific coastal warming events of 1982-83 and 1940-41. Fish Oceanogr 1: $57-79$

Tabata S (1976) The general circulation of the Pacific Ocean and a brief account of the oceanographic structure of the North Pacific Ocean Part II-thermal regime and influence on the climate. Atmosphere 14:1-27

Tabata S (1985) El Niño effects along and off the Pacific coast of Canada during 1982-83. In: Wooster WS, Flaherty DL (eds) El Niño Northi Niño effects in the eastern subarctic Pacific Ocean. Washington Sea Grant Program, Seattle, p 85-96

Tabata S, Peart JL (1985) Statistics of oceanographic data based on hydrographic/STD casts made at Ocean Station P during August 1956 through June 1981. Can Data Rep Hydrogr Ocean Sci 31

Veit RR, Pyle P, McGowan JA (1996) Ocean warming and long-term change in pelagic bird abundance within the California current system. Mar Ecol Prog Ser 139:11-18

Ware DM, McFarlane GA (1995) Climate-induced changes in Pacific hake (Merluccius productus) abundance and pelagic community interactions in the Vancouver Insland upwelling system. In: Beamish RJ (ed) Climate change and northern fish populations. Can Spec Publ Fish Aquat Sci 121:509-521

Welch DW, Ward BR, Smith B, Whitney F (1997) Changes associated with the 1989-90 ocean climate shift, and effects on British Columbia steelhead (O. mykiss) populations. Pac Stock Assess Rev Comm Work Pap S97-7

Wheeler PA (1993) New production in the subarctic Pacific Ocean: net changes in nitrate concentrations, rates of 
nitrate assimilation and accumulation of particulate nitrogen. Prog Oceanogr 32:137-161

White WB (1994) Slow El Niño-Southern Oscillation boundary waves. J Geophys Res 99:22737-22751

Wong CS, Whitney FA, Iseki K, Page JS, Zeng J (1995) Analysis of trends in primary productivity and chlorophyll-a over two decades at Ocean OSP $(50 \mathrm{~N}, 145 \mathrm{~W})$ in the Subarctic Northeast Pacific Ocean. In: Beamish RJ (ed) Cli-

Editorial responsibility: Peter Wangersky,

Victoria, British Columbia, Canada mate change and northern fish populations. Can Spec Publ Fish Aquat Sci 121:107-117

Woods J, Barkmann W (1993) The plankton multiplier - positive feedback in the greenhouse. J Plankton Res 15:1053-1074

Wooster WS, Hollowed AB (1995) Decadal-scale variations in the eastern subarctic Pacific. I. Winter ocean conditions. In: Beamish RJ (ed) Climate change and northern fish populations. Can Spec Publ Fish Aquat Sci 121:81-85

Submitted: January 10, 1998; Accepted: June 8, 1998 Proofs received from author(s): August 17, 1998 